\title{
Cost-benefit analysis of sheep and goat brucellosis vaccination with Rev.1 in the North of Portugal from 2000 to 2005
}

\author{
[Análise de custo-benefício da vacinação com Rev.1 da brucelose ovina e caprina \\ no Norte de Portugal entre 2000 e 2005] \\ A.M. Coelho ${ }^{1}$, M.L. Pinto ${ }^{2}$, A.C. Coelho ${ }^{2 *}$ \\ ${ }^{1}$ Direcção Geral de Veterinária, Divisão de Intervenção Veterinária de Vila Real, \\ Núcleo do Corgo, Lugar de Codessais - Vila Real, Portugal \\ ${ }^{2}$ Departamento de Ciências Veterinárias, CECAV - Universidade de Trás-os-Montes e Alto Douro \\ Apartado 202 \\ 5001-801 - Vila Real, Portugal
}

\begin{abstract}
In the North of Portugal, a mass vaccination programme of small ruminants was conducted from 2001 to 2004. A study of cost-benefit was carried out for the 2000/2005 period to ascertain the economic benefits of this strategy. In order to estimate the cost of the zoonosis, the compensation costs paid to farmers for culled animals in the Brucellosis Eradication Campaign, data from vaccine Rev. 1 costs, and costs of people internment due to brucellosis were studied. An increase in the cost was observed from 2000 to 2001 (aproximately US\$ 110,000), essentially due to compensation for culled animals, but also from vaccination and human internment costs. However, a progressive decrease was observed from 2001 to 2004 (from more than US\$1,200,000 in 2001 to US $\$ 180,000$ in 2004), roughly US\$1,020,000 less. As the main conclusion, the annual cost of this zoonosis decreased by an average of almost US\$600,000 per year, and a total of more than three million dollars were saved from 2000 to 2005. The results of this study suggest that mass vaccination with Rev. 1 reduced overall costs and was effective in reducing animal and human brucellosis costs.
\end{abstract}

Keywords: brucellosis, vaccination, cost-benefit

\section{RESUMO}

No norte de Portugal, procedeu-se à vacinação massiva contra a brucelose em pequenos ruminantes entre 2001 e 2004. Neste estudo, efetuou-se uma análise de custo benefício entre 2000 e 2005 para apurar os benefícios econômicos dessa estratégia. Para estimar o custo da zoonose, estudaram-se três variáveis: a indenização paga aos proprietários dos animais eliminados durante a campanha de erradicação da brucelose, o custo da vacina Rev. 1 e os custos de internamento das pessoas infectadas por brucelose nas unidades de Serviços de Saúde. Durante os anos em estudo, observou-se um aumento de custo de aproximadamente US\$110.000, entre 2000 e 2001, principalmente, devido à indenização dos animais eliminados e à aplicação da vacina e os custos por internamento de pessoas infectadas, seguindo-se uma redução acentuada entre 2001 e 2004 (de US\$1.200.000 para US\$180.000 em 2004), o que perfez US\$1.020.000 poupados. O custo anual da zoonose, em relação às variáveis estudadas, diminuiu em média US\$600.000 por ano, sendo poupados mais de US\$3.000.000 entre 2000 e 2005. Estes resultados sugerem que a vacinação com Rev. 1 reduziu os custos totais da infecção humana e animal relativamente às variáveis estudadas.

Palavras-chave: brucelose, vacinação, custo-benefício

Recebido em 6 de novembro de 2009

Aceito em 22 de dezembro de 2010

*Autor para correspondência (corresponding author)

E-mail: accoelho@utad.pt 


\section{INTRODUCTION}

Cost-benefit analysis has become a widely used technique in public policy-making due to the widespread interest in observing the tangible economic benefits of a given strategy (Levenstein and Dunn, 2005).

Brucella melitensis infection often occurs in sheep and goats and is highly pathogenic for humans, causing one of the most serious zoonosis in the world (Office..., 2009). Eradication of brucellosis in animals is a necessary step to control the human form of the disease (Corbel, 1997). Brucellosis causes heavy economic losses in animal production resulting from clinical disease, abortion, neonatal losses, reduced fertility, decreased milk production, and emergency slaughtering of the infected animals (Ariza et al., 2000). The disease is also an impediment to free animal movement and export (Al-Majali, 2005).

According to Nicoletti (1990), World... (1997), and Kumbe et al. (2005), vaccination is the main form of brucellosis control. The advantages of sheep and goat brucellosis vaccination with Rev. 1 - the vaccine used in sheep and goats against Brucella melitensis - has been unequivocally referenced by several authors (Blasco, 1997; Scharp et al., 1999; European..., 2001; Blasco, 2006), and some of these authors, in certain circumstances, defend mass vaccination (Scharp et al., 1999; Blasco, 1997; 2006) by the conjunctival route (Blasco, 1997).

The aim of this work was to study the cost and benefits of a mass vaccination against brucellosis in Portugal.

\section{MATERIAL AND METHODS}

The Northeast (Trás-os-Montes and Alto Douro) is the region of Portugal with the highest prevalence of brucellosis at herd and individual levels. A mass vaccination by conjunctival route in small ruminants with Rev. 1 was implemented from 2001 to 2004 in the region. The aim of this work was to study the cost and benefits of these measures, by comparing the year before mass vaccination (2000) with the years of vaccination (from 2001 to 2004), and the year after mass vaccination (2005).
In Trás-os-Montes and Alto Douro, as in other regions of Portugal, an animal was deemed positive if it tested seropositive for antibodies against Brucella species using the Rose Bengal plate-agglutination test (RBT) and Complement Fixation test (CFT), in accordance with the Portuguese legislation. Positive animals were culled. For each slaughtered animal, the farmer received compensation from a service of the Portuguese State according to regulations based on the species, breed, and age of the animal.

Human brucellosis must be reported as soon as it is diagnosed, and the Portuguese Human Health Services have a national register of incidence of this disease, and of the internment costs. The values were calculated by euro conversion (used in Portugal for the payments) into \$US for the euro quotation, according to the economic index.

This investigation included the indirect cost of compensation for culled (slaughtered) animals and vaccine costs and excluded costs such as an increase/decrease in abortions, premature parturition, fertility, milk production, and genetic aspects because these values were not available. Total values of compensation for each year from 2000 to 2005 were obtained from the service of the Portuguese State.

The total price spent on vaccines was provided by the Central Veterinary Services of Portugal (DGV) and the producing laboratory. The cost of each vaccine was multiplied by the number of vaccines applied in this region. It was not possible to calculate the price of the application of the vaccine because this was included in the complete official brucellosis eradication campaign of small ruminants, and it was not detailed.

It was not possible to analyze how much was spent on treating each person infected with brucellosis because the Portuguese State only pays internment costs and this is the only statistical data available in Portugal about the human disease. In order to evaluate internment costs, the central Human Health Services of Portugal (DGS) informed the costs of people internments per year with the disease in the study area. Global costs were calculated using the three variables: compensation, vaccine costs in animals, and the internment costs due to human brucellosis. 
Incremental cost data per year were analyzed from 2000 to the following years (i.e. 2000 to 2001, 2000 to 2002, 2000 to 2003, 2000 to 2004, and from 2000 to 2005). Monetary costs saving from 2000 to 2005 due to the mass vaccination programme were also analyzed.

\section{RESULTS AND DISCUSSION}

Cost-benefit analysis has become a widely used technique in public health (Levenstein and Dunn, 2005). In this study, the measurable costs of the Official Brucellosis Eradication Campaign (compensation for culled animals, vaccine costs, and cost of people internment due to brucellosis) in the region were estimated at US\$1,097,974 in 2000; US\$1,208,473 in 2001; US\$596,761 in 2002; US\$252,565 in 2003; US178,221 in 2004; and US235,284 in 2005 (Table 1). Compensation costs paid to farmers increased from 2000 to 2001, decreased from 2001 to 2004, and slightly increased in 2005. The vaccine cost was minimal in each year when compared to the other costs. The highest value corresponds to the beginning of the massive vaccination programme in 2001.

Table 1. Measurable costs in US\$ spent due to sheep and goats brucellosis, in Trás-os-Montes e Alto Douro (2000-2005), Portugal

\begin{tabular}{ccccc}
\hline Year & $\begin{array}{c}\text { Compensation costs paid } \\
\text { to farmers }\end{array}$ & Vaccine costs & $\begin{array}{c}\text { Cost of people's } \\
\text { internments }\end{array}$ & Total \\
\hline 2000 & 932,330 & 927 & 164,718 & $1,097,974$ \\
2001 & $1,047,687$ & 20,519 & 140,267 & $1,208,473$ \\
2002 & 485,825 & 11,178 & 99,758 & 596,761 \\
2003 & 194,178 & 10,765 & 47,622 & 252,565 \\
2004 & 131,323 & 17,071 & 29,826 & 178,221 \\
2005 & 225,635 & 5,889 & 3,761 & 235,284 \\
Total & $3,016,978$ & 66,348 & 485,952 & $3,569,278$ \\
\hline
\end{tabular}

The internment costs of human brucellosis had a substantially decreased from 2000 to 2005. Monetary costs saved and expensed due to the vaccination programme with Rev. 1 are present in Table 2. In the five years of the study, more than US\$3,000,000 was saved with an annual average reduction in monetary costs of US\$603,714. The annual average saving in costs of compensation paid to farmers and cost of people internment were US\$515,400 and US\$100,471, respectively.

Table 2. Total incremental costs in \$US with vaccination of small ruminant in Trás-os-Montes e Alto Douro (2000-2005), Portugal

\begin{tabular}{ccccccccc}
$\begin{array}{c}\text { Difference } \\
\text { between the } \\
\text { years }\end{array}$ & \multicolumn{2}{c}{$\begin{array}{c}\text { Compensation costs } \\
\text { paid to farmers }\end{array}$} & \multicolumn{2}{c}{ Vaccine costs } & \multicolumn{2}{c}{$\begin{array}{c}\text { Cost of people } \\
\text { internments }\end{array}$} & \multicolumn{2}{c}{ Total } \\
\cline { 2 - 9 } & Spend & Saved & Spend & Saved & Spend & Saved & Spend & Saved \\
\hline $2000-2001$ & 115,357 & - & 19,592 & - & - & 24,451 & 110,498 & - \\
$2000-2002$ & - & 331,148 & 29,843 & - & - & 89,411 & - & 390,716 \\
$2000-2003$ & - & $1,069,300$ & 39,681 & - & - & 206,507 & - & $1,236,125$ \\
$2000-2004$ & - & $1,870,307$ & 55,826 & - & - & 341,399 & - & $2,155,879$ \\
$2000-2005$ & - & $2,577,002$ & 60,788 & - & - & 502,356 & - & $3,018,569$ \\
Mean/year & - & 515,400 & 12,158 & - & - & 100,741 & - & 603,714 \\
\hline
\end{tabular}

Cost-benefit analysis should look at a method's theory and practice, detailing its advantages and shortcomings in application, and should give several ways in which the process can be made accountable (Sheldon et al., 2001). In this study, it was possible to study three variables because only these data were available.
In a cost-benefit analysis of the vaccination of sheep and goats against brucellosis, several factors such as the cost of the disease in livestock due to cull of seropositive-testing animals must be considered. In addition to the significant worldwide economic losses due to brucellosis infection in livestock, from direct losses such as 
mortality costs for example, there are other significant economic losses, such as those caused by premature parturition, decreases of fertility and milk production, high scrap rate, and slowness in genetic improvement (Amador and Valentim, 2000).

The restrictions on the milk trade and animal movement of infected herds also represent high economic losses for the herds involved. In another way, the cull of productive animals represents a great loss for the country, not only due to the loss of the animal itself, but also the number of lambs or kids and milk that the animal could have produced over the course of its productive life.

But there are also indirect costs, such as vaccine costs, wages paid to veterinary surgeons, compensation paid to farmers (for culled animals), human infection costs (for permanent or temporary incapacity), and the wages paid to doctors and their auxiliary staff. In the social aspect, human brucellosis leads to productivity losses with reductions or loss of wages due to absenteeism, on top of hospital and therapy costs (Takkouche and Otero, 1996; Amador and Valentim, 2000).

The results of this study are in agreement with previous studies. Roth et al. (2003) concluded that if the overall costs of vaccinating livestock against brucellosis were allocated to all sectors in proportion to the benefits that would be gain, these interventions could prove profitable and cost effective for both the agricultural and health sectors. So, as human brucellosis originates essentially from livestock and livestock products, the health sector is expected to profit if brucellosis in domestic animals is controlled.

\section{CONCLUSIONS}

Mass vaccination decreased human and animal brucellosis and, consequentially, the amounts paid in animal compensation were shown to decrease in this cost-benefit analysis. Despite the limitations of this study, the results of this analysis suggest that mass vaccination with Rev. 1 reduced overall costs and was effective in reducing sheep and goat as well as human brucellosis costs.

\section{ACKNOWLEDGEMENTS}

The authors would like to thank Dr. Ana Paula Figueiras and Dr. Alfredo Sobral from the Regional Veterinary Service; Dr. Teresa Martins and Dr. José Gíria from the Portuguese Central Health Service; all the staff of the Regional Human Health Institutions; and Dr Sofia Quintans, Dr. Rui Valentim, and Dr. Rita Amador from the Portuguese Central Veterinary Service.

\section{REFERENCES}

AL-MAJALI, A.M. Seroepidemiology of caprine brucellosis in Jordan. Small Rum. Res., v.58, p.13-18, 2005.

AMADOR, R.; VALENTIM, R. Brucelose. Lisboa: DGV, 2000

ARIZA, J.; CORREDOIRA, J.; PALLARES, R. et al. Characteristics of and risk factors for relapse of brucellosis in humans. Clin. Infect. Dis., v.20, p.12411249, 1995.

BLASCO, J.M. A Review of the use of B. melitensis Rev. 1 vaccine in adult sheep and goats. Prev. Vet. Med., v.31, p.275-283, 1997.

BLASCO, J.M. Classical and new generation vaccinnes against $B$. melitensis infection in small ruminants. In: INTERNATIONAL RESEARCH CONFERENCE FOR BRUCELLOSIS IN SMALL RUMINANTS, 2005, Skopje. Proceedings...Skopje, Macedonia, 2005.

BLASCO, J.M. Existing and future vaccines against brucellosis in small ruminants. Small Rum. Res., v.62, p.33-37, 2006.

BOSSERAY, N. Control methods and thresholds of acceptability for antibrucella vaccines. Dev. Biol. Stand., v.79, p.121-128, 1992.

CORBEL, M.J. Brucellosis: an overview. Emerg. Infect. Dis., v.3, p.213-221, 1997.

EUROPEAN COMMISSION. Brucellosis in sheep and goats (Brucella melitensis). Scientific Committee on Animal Health and Animal Welfare, 2001.

KUMBE, I.; PRANVERA, R.; LULJETA, D. et al. Control strategy of brucellosis in small ruminants in Albania based on its serological profile. In: INTERNATIONAL RESEARCH CONFERENCE FOR BRUCELLOSIS IN SMALL RUMINANTS, 2005, Skopje. Proceedings...Skopje, Macedonia, 2005. 


\section{Cost-benefit analysis...}

LEVENSTEIN, C., DUNN, M.L. Show me the money cost-benefit analysis in the work environment. New Solutions, v.15, p.261-276, 2005.

NICOLETTI, P. Vaccination against Brucella. Adv. Biotechnol. Proc., v.13, p.147-168, 1990.

OFFICE INTERNATIONAL DES ÉPIZOOTIES. Caprine and ovine brucellosis, 2009. Available in: $<$ http://www.oie.int/eng/normes7MMANUAL/A_000 69.htm/>. Accessed in: July 5, 2009.

ROTH, F.; ZINSSTAG, J.; ORKHON, D. et al. Human health benefits from livestock vaccination for brucellosis: case study. Bull. World Health Organ., v.81, p.867-876, 2003.

SCHARP, D.W.; AL KHALAF, S.A.S., AL MUHANNA, M.W. et al. Use of mass vaccination with a reduced dose of Rev. 1 vaccine for Brucella melitensis control in a population of small ruminants. Trop. Anim. Health Prod., v.31, p.135-141, 1999.
SHELDON, R.; O’BRIAEN, B.J.; BLACKHOUSE, G. et al. Effect of clinical risk stratification on costeffectiveness of the implantable cardioverterdefibrillator. The Canadian implantable defribilattor study. Circulation, v.2, p.1622-1626, 2001.

TAKKOUCHE, E.B.; OTERO, J.J.G. La nueva cara de la brucellosis humana: epidemiología, diagnóstico, clínica y prevención. Santiago de Compostela: Universidade, Serviço de Publicações e Intercâmbio Científico, 1996.

WORLD HEALTH ORGANIZATION. The Development of New/Improved brucellosis vaccines. Geneva: WHO/EMC/ZDI/98.14, 1997. 